\title{
NOTES
}

\section{RACE-BASED EQUAL PROTECTION CLAIMS AFTER SHAW V. RENO}

\author{
ROBERT A. CURTIS
}

\section{INTRODUCTION}

In Shaw v. Reno, ${ }^{1}$ the U.S. Supreme Court held that the North Carolina legislature's creation, pursuant to the Voting Rights Act, ${ }^{2}$ of a majority-minority voting district ${ }^{3}$ of "dramatically irregular shape", gave rise to an equal protection claim under which rehef could be granted. ${ }^{5}$ Given the convoluted nature of the Court's opimion, ${ }^{6}$ coupled with the prominence accorded by the Court to the appearance of the district, many commentators have concluded that Shaw is an anomalous decision of limited applicability, relevant only to cases in which votimg districts are of highly irregular shape. ${ }^{7}$ This Note refers to this interpretation of Shaw as the "irregular shape" rationale. If the observations of such commentators are correct, then Shaw should have little effect on equal protection jurisprudence generally. This Note argues that these commentators have misinterpreted the rationale of Shaw. Following the Court's landmark affirmative action case City of

1. 113 S. Ct. 2816 (1993).

2. 42 U.S.C. $\& 1973$ (1988).

3. A majority-minority district is one in which the majority of voters are of an ethnic or racial minority.

4. Shaw, $113 \mathrm{~S}$. Ct. at 2820 .

5. Id. at 2828 .

6. "Shaw is challenging intellectually precisely because it is so puzzling legally. Untangling its reasoning requires considerable effort." Richard $H$. Pildes \& Richard G. Niemi, Expressive Harms, "Bizarre Districts," and Voting Rights: Evaluating Election-District Appearances After Shaw v. Reno, 92 Mich. L. Rev. 483, 486 (1993).

7. Id. at 495 ("Shaw is best read as an exceptional doctrine for aberrational contexts rather than as a prelude to a sweeping constitutional condemnation of race-conscious redistricting."); see also T. Alexander Aleinikoff \& Samuel Issacharoff, Race and Redistricting: Drawing Constitutional Lines After Shaw v. Reno, 92 MrCH. L. REv. 588, 602-03 (1993); Daniel D. Polsby \& Robert D. Popper, Ugly: An Inquiry into the Problem of Racial Gerrymandering Under the Voting Rights Act, 92 MICH. L. REv. 652, 654 (1993) ("North Carolina's Twelfth District was simply too ugly to be legal."). 
Richmond v. J.A. Croson Co. ${ }^{8}$ Shaw is the next logical step in the development of the Court's equal protection jurisprudence. Under this interpretation, which this Note refers to as the "traditional" rationale, Shaw stands for the proposition that any official racial classification creates a presumption of invidiousness that can be rebutted only if the classification passes strict scrutiny. ${ }^{9}$ Under the traditional rationale, the Court's opimion explains how the facts of Shaw satisfy the traditional requirement for stating an equal protection claim: that a state policy or law has been enacted with an invidiously discriminatory purpose. ${ }^{10}$ Essential to this argument is a subsidiary argument: Shaw's contribution to equal protection jurisprudence is the recognition that racial classification is, in itself, presumptively invidious. ${ }^{11}$

Part I of this Note briefly sets out the relevant factual background of the case. Part II argues that the irregular shape inter-

8. 488 U.S. 469 (1989) (holding that the City of Richmond's plan to award a fixed number of city construction contracts to minority-owned business enterprises was subject to strict scrutiny).

9. To pass strict scrutiny, the state must prove that the legislation is narrowly tailored to attain a compelling state interest. E.g., McLaughlin v. Florida, 379 U.S. 184, 192 (1964).

10. E.g., Washington v. Davis, 426 U.S. 229, 240 (1976) (stating that it is a "basic equal protection principle that the invidious quality of a law claimed to be racially discriminatory must ultimately be traced to a racially discriminatory purpose"). Since the Supreme Court decided Shaw, two district courts have had to apply the rationale of Shaw to irregularly shaped districts. In Shaw v. Hunt, 1994 U.S. Dist. LEXIS 11102, at *4 (E.D.N.C. Aug. 1, 1994), the district court substantially adopted the traditional rationale, but it nevertheless held that the plan passed strict scrutiny. Also confronted with an extremely irregularly shaped voting district, the district court in Hays v. Louisiana, 839 F. Supp. 1188, 1206-07 (W.D. La. 1993), adopted the irregular shape interpretation by holding that the Shaw cause of action depends on the extremely irregular shape of the district. The court in Hays found that the redistricting plan at issue failed strict scrutiny. Id. at 1209.

11. Korematsu v. United States, 323 U.S. 214, 216 (1944), recoguized that race-based classification is presumptively suspect, but it did not make the further claim that the classification is itself a constitutionally cognizable lrarm. Brown v. Board of Education, 347 U.S. 483, 493-94 (1954), recoguized that race-based classification in the field of public education is harmful, but not that race-based classification in and of itself is harmful. The cognizable harm in Brown was the stigmatization or feeling of inferiority caused by the classification, not the racial classification itself. Id. at 494; see also ANDREW KULL, THE COLOR-BLIND CONSTITUTION 154 (1992) ("Taken at face value, the opinion necessarily implied that there was nothing wrong with racial segregation in and of itself: 'separate but equal' facilities, were they only attainable, would be as constitutional as ever."). Under the traditional rationale, Shaw goes beyond both of these cases in that it recognizes the very fact of racial classification, without anything more, as a cognizable harm. Shaw v. Reno, 113 S. Ct. 2816, 2824 (1993). 
pretation is untenable. First, it is inconsistent with important parts of the opinion itself. Second, it requires the adoption of an unworkable theory of harm. ${ }^{12}$ Moreover, it is incompatible with the law of standing. ${ }^{13}$ Part III sets out the traditional rationale interpretation of Shaw. The discussion briefly outlines the requirements of a traditional equal protection claim, explains how the Court's opinion is structured to meet these requirements, and then explores the Shaw Court's implicit theory of harm, which is the next logical step in the Court's equal protection jurisprudence. The discussion then considers and responds to the principal objections to the traditional rationale interpretation of Shaw. The Note concludes that the importance of Shaw goes far beyond voting districts with irregular shapes. Shaw makes it much easier for plaintiffs to survive motions to dismiss in race-related equal protection claims. All that is required in post-Shaw equal protection jurisprudence is to allege official, purposeful, racially motivated classification.

Shaw is the first case to depend on the theory that racial classification itself is presumptively harmful. ${ }^{14}$ Prior to Shaw, stating an equal protection clain based on a racial classification required alleging both purposeful racial discrimination and separate harmful effects. ${ }^{15}$ The traditional rationale interpretation of Shaw

12. See Pildes \& Niemi, supra note 6 , at $506-08$.

13. The Supreme Court has announced that three factors, derived from Article III of the Constitution, are required for standing. First, the plaintiff must allege that she has suffered, or is under imminent threat of suffering, an injury. Second, the plaintiff must allege causation: that the injury is fairly traceable to the defendant's conduct. Third, the plaintiff must allege that a favorable decision by a federal court is likely to redress the injury. Valley Forge Christian College v. Americans for the Separation of Church \& State, 454 U.S. 464,472 (1982). The irregular shape interpretation cannot meet the injury requirement. This interpretation requires a theory of nonpersonalized harm that runs afoul of the ban on generalized grievances. See infra note 55 and accompanying text.

14. Professors Aleinikoff and Issacharoff claim that "[i]t is noteworthy that Croson is the first case to invalidate an affirmative action program in which the Court did not identify any individual who had been deprived of a vested interest or expectation as a result of the plan." Aleinikoff \& Issacharoff, supra note 7, at 599. The operative language here is not "vested interest or expectation" but rather "individual," for the Croson Court noted that "[t]he Richmond Plan denies certain citizens the opportunity to compete for a fixed percentage of public contracts." City of Richmond v. J.A. Croson Co., 488 U.S. 469, 493 (1989) (plurality opinion). Croson clearly was a case in which the plaintiffs alleged a deprivation of a vested interest or expectation, namely, the opportunity to compete. In contrast to Croson, Shaw is the first case in which the Court has recognized a harm that was not the deprivation of a "vested interest or expectation." See infra notes 84-121 and accompanying text.

15. See infra notes $28-29$ and accompanying text. 
merges these categories. Alleging purposeful racial discrimination is enough to state a claim; the harmful or invidious quality follows analytically from the existence of discrimmation.

A hypothetical voting rights case demonstrates the importance of deciding between the competing interpretations. Suppose plaimtiffs have filed a complaint alleging that their state's racially motivated vote-districting plan violates the Equal Protection Clause, but are unable to show either that the voting strength of their group has been diluted or that the district at issue is of a highly irregular shape. ${ }^{16}$ Under the irregular shape interpretation, the complaint should be dismissed for failure to state a claim. Although the plaintiffs would have sufficiently alleged a discriminatory purpose, there would be no grounds on which to claim harmful or invidious effects because there would be neither vote dilution nor a district of highly irregular shape. Under the traditional rationale interpretation, however, the coinplaint would survive a motion to dismiss because Shaw recognizes that racial classification is itself presumptively invidious.

\section{FACTUAL BACKGROUND}

The event giving rise to Shaw was the redistricting of North Carolina into twelve congressional districts, including one majorityminority district. ${ }^{17}$ Because forty of the state's one hundred counties are covered by section 5 of the Voting Rights Act, ${ }^{18}$ the North Carohina General Assembly submitted its original redistricting plan to the U.S. Attorney General for preclearance. The Attorney General's office, however, formally objected to the plan. ${ }^{19}$ In response, the General Assembly adopted the revised plan

16. See, e.g., United Jewish Org. v. Carey, 430 U.S. 144, 165-66, 180 (1977) (dismissing suit for failure to state claim on grounds that in absence of vote dilution, state's consideration of race in its districting decisions does not present an injury).

17. Shaw v. Reno, 113 S. Ct. 2816, 2820 (1993).

18. The Voting Rights Act of 1965 , Pub. L. No. 89-110, \& 5, 79 Stat. 437, 439 (codified at 42 U.S.C. $\S 1973 \mathrm{c}$ (1988)). In jurisdictions covered by the special provisions of $\S$ 5 , any change in "voting qualification or prerequisite to voting, or standard, practice, or procedure with respect to voting" must be submitted to either the U.S. District Court for the District of Columbia or the U.S. Attorney General for approval. Id. Such changes are not to be approved if the changes have either the purpose or effect of denying or abridging the right to vote on the basis of color or race. Id.

19. Shaw, 113 S. Ct. at 2820. 
(hereafter the "Plan") at issue in Shaw. The Plan included a second majority-minority district. ${ }^{20}$

The First Congressional District, the original majority-minority district, is hook-shaped. Centered in the northeast portion of the state, it moves southward, until "with finger-like extensions, it reaches far into the southern-most part of the State."21 The second majority-minority district, the Twelfth Congressional District, is described in the opinion as "approximately 160 miles long and, for much of its length, is no wider than the I-85 corridor."22

The plaintiffs in Shaw filed an action in federal district court claiming, among other things, that the Plan was unconstitutional under the Equal Protection Clause. ${ }^{23}$ The three-judge district court $^{24}$ dismissed the action for failure to state a clain. ${ }^{25}$ On appeal, the Supreme Court reversed, ${ }^{26}$ holding that the plaintiff's allegations were sufficient to state an equal protection claim.

\section{THE IRREgular Shape INTERPRETATION}

\section{A. The Arguments for the Irregular Shape Interpretation}

Any plausible interpretation of Shaw must not only make sense of the text in its own terms, but also explain how the plaintiffs stated an equal protection claim. ${ }^{27}$ Under the standard formulation, to state an equal protection claim, a plaintiff must allege two things: first, that she was the object of purposeful discrimination ${ }^{28}$ and second, that the discrimination was invidious, i.e., that it has injured her. ${ }^{29}$

Under the irregular shape interpretation, discriminatory purpose is not problematic. ${ }^{30}$ The irregular shape interpretation as-

20. Brief for Appellee at 4-5, Shaw v. Reno, 113 S. Ct. 2816 (1993) (No. 92-357).

21. Shaw, $113 \mathrm{~S}$. Ct. at 2820.

22. Id. at 2820-21.

23. Shaw v. Barr, 808 F. Supp. 461,469 (E.D.N.C. 1992) (three-judge court), rev'd sub nom. Shaw v. Reno, 113 S. Ct. 2816 (1993).

24. 28 U.S.C. $\$ 2284$ (a) (1988) requires a three-judge court when there is a challenge to the apportionment of a congressional district or any statewide legislative body.

25. Shaw, 808 F. Supp. at 473.

26. Shaw, 113 S. Ct. at 2830, 2832. 28 U.S.C. $\S 1253$ (1988) provides for direct appeal to the Supreme Court from a three-judge court.

27. Shaw, 113 S. Ct. at 2832 ("Today we hold only that appellants have stated a claim under the Equal Protection Clause ....").

28. Washington v. Davis, 426 U.S. 229, 238-39 (1976).

29. See id. at 243 (affirming racial impact of the law as a necessary factor).

30. See Aleinikoff \& Issacharoff, supra note 7, at 608 ("[T]here can be no doubt 
sumes that purposeful compliance with a federal statute apparently requiring race-consciousness is no different from race-consciousness per se. Consequently, North Carolima's intent to comply with the Voting Rights Act constituted the kind of racially discriminatory purpose necessary to state an equal protection claim.

It is more difficult under the irregular shape interpretation to define an acceptable theory of harm. Given the Court's fixation ${ }^{31}$ on the shape of the Twelfth District, however, the visual appearance of the district is a natural candidate for the theory of injury einbedded in Shaw. In reapportionment cases, the Court claimed, "appearances do matter." 32 Thus, under the irregular shape interpretation, appearances matter in determining whether the discrimination has been harmful. According to the Court, districts of highly irregular shape bear "an uncomfortable resemblance to political apartheid."33 Moreover, such districts reinforce "the perception that meinbers of the same racial group," regardless of other significant demographic differences, "share the same political interests, and will prefer the saine candidates at the polls." ${ }^{34}$ Consequently, districts of highly irregular shape "may exacerbate the very patterns of racial bloc voting that majority-minority districting is sometimes said to counteract." ${ }^{35}$ The signals these districts send are "altogether antithetical to our system of representative democracy." is to conclude that voting districts of highly irregular shape generate unacceptable perceptions and that these perceptions injure the meinbers of the district in question. ${ }^{37}$

that, on the record before the Court, the decision to create the challenged district was race dependent.").

31. In the first part of the opinion, setting out the facts of the case, the Court devoted 50 lines of text to a description of the voting districts involved. Shaw v. Reno, 113 S. Ct. 2816, 2820-21 (1993). As Professors Aleinikoff and Issacharoff remark, "The shape of the district seems quite clearly to lie at the core of the Court's judgment." Aleinikoff \& Issacharoff, supra note 7, at 609 . The Court referred to the district as "bizarre on its face," Shaw, $113 \mathrm{~S}$. Ct. at 2825, and as "extremely irregular on its face," id. at 2824.

32. Id.

33. Id.

34. Id.

35. Id.

36. Id.

37. Pildes \& Niemi, supra note 6, at 493 (arguing that the injury in Shaw involved expressive, rather than material, harms focusing on the perceived legitimacy of political structures, rather than on the actual distribution of political power). 
The type of harm rehed on by the irregular shape interpretation can be usefully referred to as "expressive," rather than "material." Expressive harms are caused by ideas or preferences expressed through government action, as opposed to material harms, which result from the more tangible consequences of government action. $^{38}$ Because expressive harms focus on social perceptions, "they imvolve the government's symbolic endorsement of certain values in ways not obviously tied to any discrete imdividualized harm. ${ }^{39}$ On the other hand, City of Richmond v. J.A. Croson Co. involved a classic material harm because the plaintiff alleged demial of an opportunity to compete for a fixed number of city contracts. ${ }^{40}$ This type of harm is concrete, individualized, and material. In Shaw, by contrast, no voters suffered a dilution of their voting power; consequently, the harm to the Shaw plaintiffs was fundamentally different from the harm suffered in the typical equal protection case..$^{41}$

Consequently, the irregular shape interpretation is able to offer a full account of how the plaintiffs im Shaw stated an equal protection claim only by relying on an expressive harm. The legislature's specified purpose of coniplying with the Voting Rights Act was tantamount to the intent to reapportion based on racial criteria. Moreover, this purpose was invidious: the highly irregular shape of the district reinforced the perception that in the voting context, race is all that niatters.

The strength of the irregular shape interpretation emanates not merely from its ability to provide a theory under which the plaimtiff stated a claim, but also from its ability to explain how Shaw is consistent with United Jewish Organizations (UJO) $v$. Carey. ${ }^{42}$ The UJO Court disimissed, for failure to state a claim,

38. Id. at 506-07 ("[Expressive harm] is not concrete to particular individuals, singled out for distinct burdens. The harm instead lies in the disruption to constitutionally underwritten public understandings about the appropriate structure of values in some public arena.").

39. Id. at 513 .

40. City of Richmond v. J.A. Croson Co., 488 U.S. 469, 493 (1989) (plurality opinion). Croson involved a plan created by the Richmond City Council to set aside a specific number of city-awarded construction contracts for minority-owned business enterprises. The plan involved a quota requiring "prime contractors to whom the city awarded construction contracts to subcontract at least $30 \%$ of the dollar amount of the contract to one or more Minority Busimess Enterprises." Id. at 477.

41. See Pildes \& Niemi, supra note 6, at 506 .

42. 430 U.S. 144 (1977). The state of New York, in response to Voting Rights Act 
the plaintiff's challenge to a reapportionment plan on the grounds that the plaintiff had failed to adequately plead a harm. ${ }^{43}$ Any plausible interpretation of Shaw nust be reconcilable with UJO, since the Shaw Court expressly distinguished Shaw from UJO.4 In UJO, a plurality of the Supreine Court approved the deliberate use of racial criteria in order to comply with section 5 of the Voting Rights Act. ${ }^{45}$

Under the irregular shape interpretation, Shaw and UJO are distinct in that they involved different kinds of injury. The Shaw Court characterized $U J O$ as a vote dilution case. ${ }^{46}$ In Shaw, according to the irregular shape interpretation, the issue was not vote dilution but the signal that highly irregular districts send. Under this reading, Shaw presented an injury because it involved a higlily irregular district. $U J O$, on the other liand, did not present an injury, since under the facts of that case, there was no vote dilution. ${ }^{47}$ The irregular shape interpretation is thus able to reconcile Shaw with UJO because the two cases turned on different theories of injury.

The irregular shape interpretation is a powerful explanation of the Court's rationale in Shaw because it is able to explain not only how the text and structure of the Court's opinion warrant its holding, but also how the rationale of Shaw is reconcilable with UJO. Despite the explanatory power of the irregular sliape interpretation, however, there are enougl difficulties with it to warrant a search for a better imterpretation of the Court's rationale.

\footnotetext{
violations, adopted a reapportionment plan that redesigned voting districts in Kings County. Id. at 149-51. The plan did not create any additional majority-minority districts, but did redistribute ininority voters in a way likely to enhance overall minority voting effectiveness. One result was that a Hasidic cominunity that had previously been located in one district was broken up into two districts. Id. at 148-52. The UJO Court upheld the plan on the grounds that New York's deliberate racial classification pursuant to the Voting Rights Act did not violate the Constitution. Id. at 167-68 (plurality opinion); see also id. at 179-80 (Stewart, J., concurring).

43. Id. at 164-65 (plurality opinion).

44. Shaw v. Reno, 113 S. Ct. 2816, 2829 (1993).

45. UJO, 430 U.S. at 164-65.

46. Shaw, 113 S. Ct. at 2829.

47. UJO, 430 U.S. at 163-64.
} 


\section{B. Objections to the Irregular Shape Interpretation}

The irregular shape interpretation suffers froin both internal and external deficiencies. The interpretation is internally deficient because it cannot explain important parts of the opinion itself; it is externally deficient because of the pressure it puts on other wellsettled areas of law. ${ }^{48}$

The primary internal deficiency of the interpretation is that it cannot explain the abundant language in Shaw suggesting that all purposeful racial classifications are subject to strict scrutiny. ${ }^{49} \mathrm{Un}$ der the irregular shape interpretation, only voting districts that have highly irregular shapes, explicable only in terms of race, are subject to strict scrutiny. Consequently, regularly shaped districts, ${ }^{50}$ even if purposefully drawn in a race-conscious fashion, would not be subject to strict scrntiny under this interpretation.

This result does not square with the Court's language that "demands strict scrutiny of all racial classifications." ny is required of such classifications because "[a] racial classification, regardless of purported motivation, is presunptively invalid and can be upheld only upon an extraordinary justification." 52 Since every purposeful racial classification is subject to strict scrutiny, hittle room is left for the claim of the irregular shape interpretation that Shaw is an aberration, applying only to irregularly shaped voting districts. Under the traditional rationale interpretation of Shaw, a plaintiff living in a regularly shaped district could require her state legislature to deinonstrate that its plan passed strict scrutiny. This result would be flatly inconsistent with the irregular shape interpretation of Shaw.

Aside froin its inability to explain a critical part of the Court's opinion, the irregular shape interpretation is in significant

48. At this point in the discussion, this Note considers only those critiques of the irregular shape interpretation that are not at the same time part of the argument for a different interpretation of Shaw. The purpose of this separation is to make clear that, on its own terms, the irregular shape interpretation is deficient. To be sure, however, the best objection to the irregular shape interpretation is the explanatory power of the traditional rationale. See infra Part III.

49. See Shaw, $113 \mathrm{~S}$. Ct. at 2824-25.

50. Broadly, a district is regularly shaped if it accords with traditional districting principles: compactness, contiguity, respect for political subdivisions, and population equality. Id. at 2827; UJO, 430 U.S. at 168; Reynolds v. Sims, 377 U.S. 533, 578 (1964).

51. Shaw, 113 S. Ct. at 2830.

52. Id. at 2825 (quoting Personnel Adm'r v. Feeney, 442 U.S. 256, 272 (1979)). 
tension with other areas of the law. First, although the theory of expressive harm that underhes the irregular shape interpretation helps explain how the plaintiffs managed to state an equal protection claim, the theory itself is open to significant criticisin. As the advocates of the irregular shape interpretation concede, granting expressive harms constitutional recognition would require judges to engage in extraordinarily difficult acts of interpretation. ${ }^{53}$ To decide whether the shape of a district is sufficiently irregular as to warrant a finding that society has been harmed by its existence would not, indeed could not, involve the apphication of a legal test. Rather, courts would have to determine the expressive power or meaning that a government policy has in a particular social, historical, and political setting. Courts would be called on not to interpret the legislature's intent, but rather to determine the social message the pohicy sends. Even advocates of the irregular shape interpretation find the indeterminacy of the expressive theory of harm problematic: "Such exercises of judicial judgment are fraught with complexity and unlikely to yield determinate, single right answers." 54

Second, and more seriously, the expressive view of harm is incompatible with the Court's ban on generalized grievances. For a party to have standing before a federal court, the party's clained imjury must be not general, but individuated. A plaintiff must be able to distinguish her claim from "a generally available grievance about government-claiming only harm to [her] and every citizen's interest in proper application of the Constitution and laws, and seeking relief that no more directly and tangibly benefits [her] than it does the public at large." 55 The fact that expressive harms are not tied to any discrete individualized harms makes the theory of harm underlying the irregular shape interpretation incompatible with the traditional requirenent of individualized wrongs. ${ }^{56}$ An

53. Pildes \& Niemi, supra note 6 , at $507-08$.

54. Id. at 508 .

55. Lujan v. Defenders of Wildilife, 112 S. Ct. 2130,2143 (1992).

56. See Pildes \& Niemi, supra note 6, at 513-14 ("Expressive harms focus on social perceptions, public understandings, and messages; they involve the government's symbolic endorsement of certain values in ways not obviously tied to any discrete, individualized harm. A significant tension, therefore, exists between recognition of expressive harms and traditional requirements of individualized wrongs."); see also Allen v. Wright, 468 U.S. 737, 754-55 (1984) (holding that abstract stigmatic injury unaccompanied by further individualized and unequal treatment is insufficient to give rise to standing). 
interpretation of the Shaw Court's rationale that requires the creation of a new cause of action is seriously flawed if that cause of action is unable to invoke the jurisdiction of a federal court. The difficulties with the irregular shape interpretation warrant exploring an alternative interpretation of the Court's rationale.

\section{ThE TRADITIONAL RATIONALE INTERPRETATION}

\section{A. The Arguments for the Traditional Rationale Interpretation}

Contrary to the claims of the irregular shape interpretation, the Shaw Court did not take discriminatory purpose for granted. The fact that the Twelfth District is of irregular shape was important not because it created a new kind of harm, but because it allowed the Court to presume that the legislature's purpose in drawing such a district was racially motivated. The injury needed to complete an equal protection claim was official race-conscious classification itself. The unique contribution of Shaw is that it makes racial classification in itself a personal, imdividualized injury. ${ }^{57}$ Although this conception of harm makes its formal debut in Shaw, it has been germinating in the Court's jurisprudence for some time..$^{58}$ Thus, Shaw represents the next logical step in the Court's jurisprudence.

The traditional rationale, so conceived, avoids the internal and external deficiencies that plague the irregular shape interpretation. These factors combine to make the traditional rationale a better interpretation of the Court's reasoning than the irregular shape interpretation. Thus, lower federal courts confronted with a racebased equal protection claim must look to Shaw for guidance in a far greater range of cases than the irregular shape interpretation would suggest.

Under the irregular shape interpretation, discriminatory purpose is inferred froin compliance with the Voting Rights Act. Thus, under this imterpretation, a reason other than establishing discriminatory intent must be attributed to the Court's language regarding the irregular shape of the district. ${ }^{59}$ To avoid making this language superfluous it is therefore necessary, under this interpretation, to use the language to explain the nature of the injury.

57. Shaw v. Reno, 113 S. Ct. 2816, 2824 (1993).

58. See infra notes $99-121$ and accompanying text.

59. Shaw, $113 \mathrm{~S}$. Ct. at $2820-21$ (describing the shape of the district). 
However, once it is seen that the Court was not taking discriminatory purpose for granted, the irregular shape language begins to make inore sense as an attempt to attribute a racial motivation to the North Carolina legislature.

The Shaw Court began by noting that "[n]o mquiry into legislative purpose is necessary when the racial classification appears on the face of the statute." ${ }^{\text {" }}$ However, the Court later explained that statutes not involving express racial classifications are substantively no different from those that do. Exacting judicial scrutiny must be applied "not only to legislation that contains explicit racial distinctions, but also to those 'rare' statutes that, although race-neutral, are, on their face, 'unexplamable on grounds other than race.' "61 This exacting scrutimy must be "applie[d] . . . to a classification that is ... an obvious pretext for racial discrimination." ${ }^{\prime 62}$ If the element of discriminatory purpose is as clear-cut as the irregular shape interpretation suggests, it is hard to postulate a reason for the Court's lengthy analysis of statutes that are facially neutral. ${ }^{63}$

The Court expressly characterized the plaintiffs' claim as requiring the inference of racial classification from the shape of the district: "Appellants contend that redistricting legislation that is so bizarre on its face that it is 'unexplainable on grounds other than race' demands the same close scrutiny that we give other state laws that classify citizens by race."64 If the allegation of discriminatory purpose followed from North Carolina's intent to comply with the Voting Rights Act, as the irregular shape interpretation clains, there would be no need for the Court to characterize the appellants' claim as requiring the inference of discriminatory purpose from the shape of the district. If the district was expressly drawn with the purpose of racial discrimination, the fact that the district's appearance was unexplainable on grounds other than race would be entirely superfluous.

As the Shaw Court's subsequent discussion of Wright $v$. Rockefeller ${ }^{65}$ illustrates, the irregular shape of the district is rele-

60. Id. at 2824 .

61. Id. at 2825 (quoting Village of Arlington Heights v. Metropolitan Hous. Dev. Corp., 429 U.S. 252, 266 (1977)).

62. Id. (quoting Personnel Adm'r v. Feeney, 442 U.S. 256, 272 (1979)).

63. Id. at 2825-28.

64. Id. at 2825 (quoting Arlington Heights, 429 U.S. at 266).

65. 376 U.S. 52 (1964). 
vant to the explanation of the legislature's purpose. Wright involved four districts created by a New York apportionment statute. ${ }^{66}$ As the Shaw Court noted, the disagreement between the majority and the dissenters in Wright was whether the plaintiff had proved that the lines were drawn with a racially discriminatory purpose. ${ }^{67}$ The Wright majority argued that although the lines were irregular, they were not so irregular as to permit no other conclusion than that they were drawn for the purpose of classifying voters by race. ${ }^{68}$ The dissenters argued that the bizarre shape of the district lines could be "explained only in racial terms."

According to the Shaw Court, Wright illustrates the difficulty of proving discriminatory purpose in the reapportionment context. ${ }^{70}$ As the Shaw Court noted, however,

The difficulty of proof, of course, does not mean that a racial gerrymander, once established, should receive less scrutiny under the Equal Protection Clause than other state legislation classifying citizens by race. Moreover, it seems clear to us that proof sometimes will not be difficult at all. In some exceptional cases, a reapportionment plan may be so highly irregular that, on its face, it rationally cannot be understood as anything other than an effort to "segregat[e] . . voters" on the basis of race."

The Court further noted that compliance with traditional districting principles is not constitutionally required. Rather, such principles are important because they are "objective factors that may serve to defeat a claim that a district has been gerrymandered on racial lines." ${ }^{\text {"2 }}$ Moreover, the Court's summary of its holding shows that it understood North Carolina's statute to be race-neutral on its face. ${ }^{73}$ Nevertheless, the Court held that the plaintiffs could state

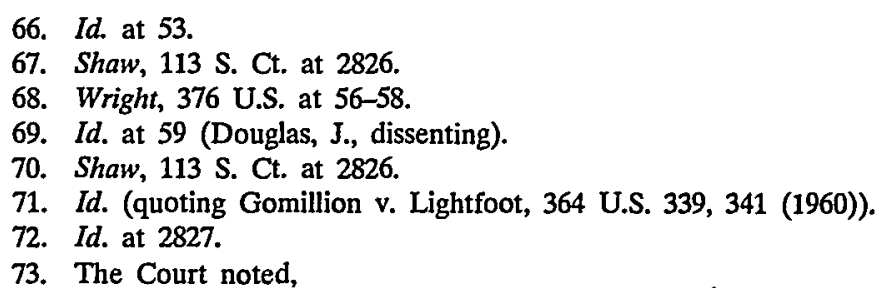

[W] conclude that a plaintiff challenging a reapportionment statute under the Equal Protection Clause may state a claim by alleging that the legislation, though race-neutral on its face, rationally cannot be understood as anything other than an effort to separate voters into different districts on the basis of race ....

Id. at 2828 . 
an equal protection claim by alleging that the shape of the district could be explained only as an attempt to classify voters on racial lines. ${ }^{74}$ The Court remanded Shaw to the district court partly in order to determine if there had been a racial gerrymander. ${ }^{75}$ If the intent to classify on racial grounds had been clear on the face of the record, the part of the remand order directing an inquiry into racial gerrymandering would have been redundant. The Court, it is important to reinember, held only that the plaimtiffs had stated a claim, i.e., that the plaintiffs' allegations regarding purpose were sufficient to go forward to a trial on the merits. Thus, the Court did not conclude that the question of discriminatory purpose was clear on the face of the record, for as it noted in Shaw, "[n]o inquiry into legislative purpose is necessary when the racial classification appears on the face of the statute. .76

This language, coupled with the content of the remand order, is simply mconsistent with the supposition that discrimmatory purpose appeared on the face of the record. Moreover, much of the Court's opinion seems to be aimed at fashioning criteria for lower courts to apply in determining whether there has been a racial gerrymander. Consequently, two propositions emerge from the Court's analysis. First, the Court was unwilling to treat North Carolina's reapportionment statute as an instance of express racial gerrymandering. Second, the Court relied on the irregular shape of the district to infer a racially discriminatory purpose. In strictly textual terms, then, the traditional rationale is able to provide a better account of the Court's focus on the odd shape of the district than is the irregular shape interpretation.

The reasons for preferring the traditional rationale's explanation of the proiminence of the district's shape, however, go well beyond the text. The treatment of discriminatory purpose by the irregular shape interpretation depends necessarily on the assumption that intentional compliance with the Voting Rights Act, which may require race-consciousness, is equivalent to imtentional raceconsciousness per se. Vahidating this assumption would put serious pressure on the constitutionality of the Voting Rights Act itself. If

74. Id.

75. Id. at 2832 ("If the allegation of racial gerrymandering remains uncontradicted, the District Court further must determine whether the North Carolina plan is narrowly tailored to further a compelling governmental interest.").

76. Id. at 2824. 
the Court were to find that the mere intent to comply with the Voting Rights Act constitutes the discriminatory purpose necessary to state an equal protection claim, the Voting Rights Act would itself be subject to strict scrutiny since it would anount to a de facto racial classification. ${ }^{7}$ Consequently, the Shaw Court expressly left open the question of whether the Voting Rights Act is itself unconstitutional, ${ }^{78}$ because the Court's prior decisions counsel against reaching the constitutionality of an act of Congress when avoiding the issue is possible. ${ }^{79}$ Specifically, the Court should invalidate an act of Congress, particularly one that addresses a "vexing national problem, only for the most coinpelling constitutional reasons." $" 80$

Consequently, there are doctrinal reasons for preferring an imterpretation of the Shaw Court's decision that do not implicate the Voting Riglits Act. Moreover, as argued above, the Court's discussion of facially neutral statutes lends strong support to the conclusion that the Court inferred discriminatory purpose from the highly irregular sliape of the district, as the traditional rationale contends, ratler than from the Voting Rights Act, as the irregular shape interpretation contends. Therefore, the best explanation of the Court's irregular sliape language is that the irregular sliape of the district allowed the Court to infer discriminatory purpose. Having located the eleinent of discriminatory purpose in the shape of the district, the traditional rationale must set out a theory of injury compatible with the Shaw Court's reasoning.

Under the traditional rationale, the injury suffered by the plaintiffs in Shaw was the mere fact of racial classification. Al-

77. See, e.g., id. at $2830-31$.

78. Id. at 2831.

79. See, e.g., Ashwander v. Tennessee Valley Auth., 297 U.S. 288, 341, 345-48 (1936) (Brandeis, J., concurring) (arguing that the Court should neither pass on the constitutionality of an act of Congress if the question can be avoided, nor anticipate a question of constitutional law before an answer to the question is absolutely necessary, nor formulate a rule of constitutional law broader than required to resolve a case). The Shaw Court, in tying the element of purpose to the shape of the district, rather than to North Carolina's intent to comply with the Voting Rights Act, adhered to these prudential doctrines. The Shaw Court was able to characterize the issue in a way that avoided passing on an act of Congress; it did not anticipate the question of whether the Voting Rights Act is itself unconstitutional since it was able to resolve Shaw without addressing that issue. Since the shape of the district sufficed as an allegation of discriminatory purpose, to address the constitutionality of the Voting Rights Act would have been a broader resolution of the issue than the facts of Shaw required.

80. Mistretta v. United States, 488 U.S. 361,384 (1989). 
though this theory of injury has been germinating in the Court's jurisprudence for some time, Shaw is the first case to rely on it for its central holding. ${ }^{81}$

The typical equal protection claim is bifurcated: it involves an allegation of discriminatory purpose coupled with an allegation that this purpose, or the attainment of this purpose, will have, or has had, certain injurious effects. ${ }^{82}$ These two allegations amount to the requirement that to state a claim, a challenged official action must have been taken with invidious discriminatory imtent. ${ }^{83}$ In other words, in pre-Shaw equal protection jurisprudence, merely alleging a purposeful racial classification was insufficient. The complaining party also had to make the separate claim that the classification had denied the party some cognizable right. The consideration of pre-Shaw equal protection cases makes this bifurcation clear.

In the landmark case of Brown v. Board of Education, ${ }^{84}$ the Court found unconstitutional the racial segregation of public schools. The plaintiffs suffered an injury, the Court held, because they had been demied their right to an equal education. ${ }^{85}$ There was thus something tangible and material, namely, an equal education, that the plaintiffs had been denied. In Loving $v$. Virginia, ${ }^{86}$ the Court held that a Virginia statute that proscribed interracial marriage violated the Equal Protection Clause. ${ }^{87}$ The plaintiffs' injury was their conviction pursuant to the statute. In Regents of the University of California v. Bakke, ${ }^{88}$ the Court held that the inedical school adımission policy of the Umiversity of Cahifornia at Davis, which established a racial quota, was subject to strict scrutiny. ${ }^{89}$ The plaintiff was able to state a claim because he had suf-

81. Though a true demonstration of this negative hypothesis would require an analysis of all equal protection cases, the proposition can be reasonably established by considering the landmark equal protection cases. See, e.g., infra notes 84-93 and accompanying text.

82. See, e.g., Washington v. Davis, 426 U.S. 229, 239 (1976).

83. Id.

84. 347 U.S. 483 (1954).

85. Id. at 492-95 (finding that segregation in education caused feelings of "inferiority," which in turn deprived plaintiffs of benefits they would have received from integrated schools).
86. 388 U.S. 1 (1967).
87. Id. at 2 .
88. 438 U.S. 265 (1978).
89. Id. at 287-91. 
fered the tangible injury of being denied equal access to a public institution. ${ }^{90}$ In City of Richmond v. J.A. Croson Co., ${ }^{91}$ the Court held that Richmond's plan to award a fixed number of construction contracts to minority-owned business enterprises was subject to strict scrutiny..$^{92}$ The plaintiff stated a claim because it had suffered the tangible injury of being denied the opportunity to compete for a fixed percentage of public contracts due too its race. ${ }^{93}$

All these cases involved allegations of both a racial classification and a particular inaterial harm. Under the traditional rationale interpretation of Shaw, this bifurcation is no longer necessary. Shaw merges these two claims: under Shaw, an allegation of racial classification analytically contams an allegation of harm. While this is a new theory of harm, its recognition is the next logical step in the Court's jurisprudence.

This theory of harm is not apparent on the face of the Court's opinion. The Court did, however, define the criteria by which a racial classification can be found bemign. ${ }^{94}$ The Court's theory of harm must be inferred from these criteria; a racial classification is invidious if it fails the test for bemign classifications. Consequently, the criteria by which the Shaw Court tested for benign classifications is the essential hink to the Court's understand$\mathrm{mg}$ of injury in the racial context.

In one of the critical passages in Shaw, setting out the test for bemign racial classifications, the Court noted that the reason

the Equal Protection Clause demands strict scrutiny of all racial classifications is because without it, a court cannot determine whether or not the discrimination truly is "benign." Thus, if appellants' allegations of a racial gerrymander are not contradicted on remand, the District Court must determine whether the General Assembly's reapportionment plan satisfies strict scrutiny. ${ }^{95}$

90. See id. at $280-81$ n.14.

91. 488 U.S. 469 (1989).

92. Id. at $493-98$.

93. Id. at 493. But see Aleinikoff \& Issacharoff, supra note 7, at 599 (arguing that the Court in Croson did not identify any individual deprived of an interest or expectation).

94. See, e.g., Shaw v. Reno, 113 S. Ct. 2816, 2830 (1993); see infra text accompanying notes $95-98$.

95. Shaw, 113 S. Ct. at 2830 (citation omitted). 
This passage has two important implications. First, the allegation of a racial gerrymander affecting the claimant, ${ }^{96}$ and nothing more, is sufficient to state a claim: the Court made clear that the allegation of a racial gerrymander triggers strict scrutiny. ${ }^{97}$ Therefore, unless the Shaw Court abandoned the traditional requirement of stating a claim (that there be discriminatory intent coupled with harmful effects), a presumption of injury inust be built into the allegation of a racially discriminatory purpose. Second, to overcome this presumption of invidiousness, an official racial classification unust pass strict scrutiny. Thus, any racial classification not narrowly tailored to pursue a compelhng state interest is invidious.

The theory of harm in Shaw, therefore, envisions the following approach to equal protection claims in the racial context: to state a claim, it is sufficient to allege a racially discriminatory purpose, because racial classification is presumed invidious. This presumption can be overcome only by demonstrating that the classification passes strict scrutiny.

In essence, strict scrutiny defines mvidiousness because it screens out all arbitrary classifications. ${ }^{98}$ As Justice O'Connor, writing for the plurality in Croson, noted,

[T] he purpose of strict scrutiny is to "smoke out" illegitimate uses of race by assuring that the legislative body is pursuing a goal important enough to warrant use of a highly suspect tool. The test also ensures that the means chosen "fit" this compelling goal so closely that there is little or no possibility that the motive for the classification was illegitimate racial prejudice or stereotype. ${ }^{99}$

96. One of the difficulties of this analysis is specifying exactly who is affected. For example, white voters in Hawaii are not affected by redistricting in North Carolina. See Allen v. Wright, 468 U.S. 737, 754-56 (1984) (holding that injury for standing purposes must be individuated). A harder question is whether white North Carolina voters living in districts not altered by the redistricting in question are affected for the purposes of determining standing. The Allen $v$. Wright requirement of individuated, unequal treatment, $i d$, suggests that the voters must belong to the districts that were drawn with discriminatory purpose in order to allege classification as an injury in the redistricting context.

97. Strict scrutiny analysis is not part of the determination of whether the plaintiff has stated a claim. See Shaw, 113 S. Ct. at 2832 (holding that plaintiff stated a claim and remanding to district court to determine if legislation passes strict scrutiny).

98. Statutes that fail rational basis review or intermediate scrutiny are similarly arbitrary and hence invidious. Strict scrutiny is used in the racial classification context because race is so strongly presumed to be irrelevant to public decisionmaking. See City of Cleburne v. Cleburne Living Ctr., Inc., 473 U.S. 432, 440 (1985).

99. City of Richmond v. J.A. Croson Co., 488 U.S. 469, 493 (1989) (plurality opill- 
The logic of this passage implies that strict scrutiny prevents racial classification from arbitrarily allocating public goods in two ways. First, it requires that the interest pursued be compelling. ${ }^{100}$ This component ensures that individuals are subject to racial classification only when powerful state interests are at stake. Second, strict scrutiny requires a narrowly tailored policy working to attain the compelling end. ${ }^{101}$ This requirement ensures that the racial classification strictly correlates with the class of people that is the object of the state's compelling interest. ${ }^{102}$ Thus, arbitrariness is avoided by ensuring that the racial classification does not benefit people who have no justified claim. When a race-conscious policy fails strict scrutiny, it is imvidious because the racial group selected for the benefit is not congruent with the group that the state has a compelling interest in treating preferentially.

Two propositions follow from this analysis. First, discrimination is invidious only if it is arbitrary. Second, racial classification is presumptively arbitrary and thus presumptively invidious. These propositions not only are logically implied by the Court's conceptualization of the importance of strict scrutiny, but also are consistent with much of the Court's established equal protection jurisprudence.

As early as 1904 , it was recognized that the touchstone of unconstitutional discrimination was arbitrary line-drawing. In Missouri, Kansas, \& Texas Railway v. Clay May, Justice Brown argued that the key to unconstitutional discrimination was line-drawing without sufficient reason. ${ }^{103}$ The cormection between arbitrariness and unconstitutional discrimination has continued into the modern era. In Hopper v. Bernalillo County Assessor, ${ }^{104}$ the Court held

ion).

100. See McLaughlin v. Florida, 379 U.S. 184, 192 (1964).

101. Id.

102. A policy that required an innocent party to pay compensation for a wrong would similarly fail the "narrowly tailored" prong of strict scrutiny. See Regents of the Univ. of Cal. v. Bakke, 438 U.S. 265, 298 (1978) ("[T]here is a measure of inequity in forcing innocent persons . . . [to redress] grievances not of their making.").

103. 194 U.S. 267, 271 (1904) (Brown, J., dissenting) (stating that a statute that imposed liability on railroad for allowing Johnson grass to grow on right-of-way but imposed no similar liability on others should be found to violate the Fourteenth Amendment, because if Johnson grass is a nuisance when growing on railroad tracks, "it is equally so when growing upon the other side of the line fence, and ... the law should be made general to avoid the charge of arbitrary discrimination").

104. 472 U.S. $612,620-22$ (1985). 
that a New Mexico statute distinguishing between "established" and nonestablished resident veterans was invidious because the distinction was arbitrary. In its most clear statement of the connection between invidiousness and arbitrariness, the Court in City of Dallas $v$. Stanglin ${ }^{105}$ noted that "it is only the invidious discrimination, the ... arbitrary act, which cannot stand consistently with the Fourteenth Amendment." ${ }^{106}$ Thus, classifications that are arbitrary are constitutionally invidious.

Just as firmly estabhished is the proposition that racial distinctions are presumptively arbitrary. Nearly thirty years ago, Justice Douglas explained in Wright $v$. Rockefeller that "the individual is inportant, not his race, his creed, or his color. ... [Racial differences between persons] are irrelevant in the constitutional sense." 107 Racial classification is presumed to be arbitrary because "laws grounded in such considerations are deemed to reflect prejudice and antipathy" and because racial factors "are so seldom relevant to the achievement of any legitimate state interest."108

The proposition that racial characteristics are arbitrary from a constitutional point of view is amplified by the Court's decision in Palmore v. Sidoti. ${ }^{109}$ Linda Sidoti Palmore and Anthony Sidoti, both white, were divorced in May, 1980; Linda was awarded custody of their three-year-old daughter Melanie. In 1981, the father challenged custody on the grounds that conditions had changed: the mother was cohabiting with a black man, Clarence Palmore, Jr., whom she married two months later. ${ }^{110}$ The district court awarded custody to the father because it felt

that despite the strides that have been made in bettering relations between the races in this country, it is inevitable that

105. 490 U.S. 19 (1989).

106. Id. at 27 (quoting New Orleans v. Dukes, 427 U.S. 297, 303-04 (1976)).

107. 376 U.S. 52, 66-67 (1964); see also City of Richmond v. J.A. Croson Co., 488 U.S. 469, 518 (1989) (Kennedy, J., concurring) ("The moral imperative of racial neutrality is the driving force of the Equal Protection Clause."); id. at 527-28 (Scalia, J., concurring) (favoring a constitutional right to be considered in a race-neutral manner); Regents of the Univ. of Cal. v. Bakke, 438 U.S. 265, 291 (1978) ("Racial and ethnic distinctions of any sort are inherently suspect and thus call for the most exacting judicial examination."); Hirabayashi v. United States, 320 U.S. 81, 100 (1943) ("Distinctions between citizens solely because of their ancestry are by their very nature odious to a free people whose institutions are founded upon the doctrine of equality.").

108. City of Cleburne v. Cleburne Living Ctr., Inc., 473 U.S. 432, 440 (1985).

109. 466 U.S. 429 (1984).

110. Id. at 430 . 
Melanie will, if allowed to renain in her present situation and attain[] school age and thus [beconie] more vulnerable to peer pressures, suffer from the social stigmatization that is sure to conie. ${ }^{111}$

The Supreme Court unanimously reversed. The Court reasoned that a central purpose of the Fourteenth Amendment "was to do away with all governmentally imposed discrimination based on race." race is more likely to reflect racial prejudice than legitimate public concerns."113 Consequently, racial classifications are "subject to the most exacting scrutiny; to pass constitutional muster, they must be justified by a compelhing governmental interest and must be 'necessary ... to the accomplishment' of their legitimate purpose."114 The state, the Court acknowledged, "has a duty of the highest order to protect" the welfare of children. ${ }^{115}$ Even though there was a risk that a child living with a stepparent of a different race might be subject to stresses and complications "not present if the child were living with parents of the same racial or ethnic origin," 116 the Court refused to find a compelling interest in protecting the child from the potential hardships caused by the mixed marriage. ${ }^{117}$ To reach this result, the Court effectively held that considerations based on race are fundamentally irrelevant to constitutional analysis. ${ }^{118}$

The plurality in Croson went a step further, claiming that distinctions based on race deny the classified citizens "their "personal rights' to be treated with equal digmity and respect."119

111. Id. at 431 (quoting Application to Petition for Certiorari at 26-27).

112. Id. at 432 (citation omitted).

113. Id.

114. Id. at $432-33$ (citations omitted).

115. Id. at 433 .

116. Id.

117. Id. at 434 .

118. The Court wrote,

The question, however, is whether the reality of private biases and the possible injury they might inflict are permissible considerations for removal of an infant child from the custody of its natural mother. We have little difficulty concluding that they are not. The Constitution cannot control such prejudices but neither can it tolerate them. Private biases may be outside the reach of the law, but the law cannot, directly or indirectly, give them effect.

Id. at 433. ion).

119. City of Richmond v. J.A. Croson Co., 488 U.S. 469, 493 (1989) (plurality opin- 
Such distinctions are constitutionally suspect because they are based on "a rigid rule erecting race as the sole criterion in an aspect of public decisionmaking." 120 Finally, in Shaw, the Court acknowledged as part of its rationale that "a racial classification ... is presumptively invalid and can be upheld only upon an extraordinary justification." 121

The Shaw Court's use of strict scrutiny imphes that any racial classification is presumptively invidious because it is presumptively arbitrary. Moreover, the proposition that racial classification is presumptively invidious is the next logical step for the Supreme Court to take, given the recent development of its jurisprudence, particularly in Croson. These two points demonstrate that the theory of injury underlying the Shaw Court's holding that the plaintiffs stated an equal protection claim is that racial classification, in itself, is presumptively invidious.

The traditional rationale succeeds in explaining how the plaintiffs in Shaw stated an equal protection claim. The Court inferred racially discriminatory purpose from the highly irregular shape of the district. Since racially discriminatory intent analytically contains a presumption of mjury, the plaintiffs succeeded im alleging a constitutionally cognizable injury. The traditional rationale is thus consonant with the text of the Court's opimion and it explains the doctrine used by the Court.

\section{B. Objections to the Traditional Rationale Interpretation}

Like the irregular shape interpretation, the traditional rationale is subject to both internal and external objections. Unlike the irregular shape interpretation, however, the traditional rationale is able to dispositively dissolve these objections.

The first objection is, "If Shaw is a run-of-the-Inill equal protection case, why would the Court pay so much attention to the 'bizarre' shape of the North Carolina district?"122 The answer to

120. Id.

121. Shaw v. Reno, 113 S. Ct. 2816, 2825 (1993) (quoting Personnel Adm'r v. Feeney, 442 U.S. 256, 272 (1979)). The full text of the relevant portion of Feeney reads, "Certain classifications, however, in themselves supply a reason to infer antipathy. Race is the paradigm. A racial classification, regardless of purported motivation, is presumptively invalid and can be upheld only upon an extraordinary justification." Feeney, 442 U.S. at 272.

122. Aleinikoff \& Issacharoff, supra note 7, at 608; see also Pildes \& Niemi, supra note 6 , at 495 : 
this objection was given above: Shaw focuses on the shape of the district only to infer discriminatory purpose. ${ }^{123}$ Thus, contrary to the irregular shape interpretation, Shaw does not suggest that regularly shaped districts drawn with discriminatory purpose are immune from constitutional criticism. Regular districts are governed by the same constitutional standards as irregularly shaped ones; the difference lies only in the difficulty of proving purpose. ${ }^{124}$

A second, and more serious, objection to the traditional rationale is that it cannot be reconciled with the Shaw Court's unwillingness to overturn United Jewish Organizations (UJO) v. Carey. ${ }^{125}$ In UJO, as in Shaw, the state legislature, pursuant to the Votmg Riglts Act, redistricted in a race-conscious manner. ${ }^{126}$ If Shaw means that race-consciousness itself is presumptively invidious, then the Court slould have overturned UJO; that is, in retrospect, the UJO plaintiff's allegations of race-consciousness ${ }^{127}$ slould have been found sufficient to state a claim. Since the Court did not reverse UJO, Shaw inust stand for a proposition other than that race-consciousness is presumptively invidious. ${ }^{128}$ The Shaw Court recognized this difficulty and accordingly distinguished Shaw from UJO in two different ways. ${ }^{129}$

First, the Shaw Court characterized UJO as something akin to a mixed motive case. Under a mixed motive analysis, a plaintiff who is able to allege discriminatory purpose fails to state a claim if the defendant can slow that the challenged action would have

[1]f race-conscious districting per se were the constitutional problem, it is difficult to rationalize the architecture of the decision. The keystone in Shaw is the "highly irregular" shape of District 12. The negative pregnant, then, is that "regular" districts desigued for race-conscious reasons do not raise similar constitutional concerns.

123. See supra notes $60-67$ and accompanying text.

124. See supra notes $60-76$ and accompanying text.

125. Shaw v. Reno, 113 S. Ct. 2816, 2829-30 (1993) (holding that Shaw does not coinpel reversal of UJO).

126. United Jewish Orgs. (UJO) v. Carey, 430 U.S. 144, 151-52 (1977).

127. Id. at 155 .

128. Pildes \& Niemi, supra note 6, at 496 n.60; see also Aleinikoff \& Issacharoff, supra note 7 , at 607 :

[Under the traditional rationale, i]f a plaintiff could successfully show that a compact district had been drawn for racial purposes-for example, the situation in UJO-the usual equal protection rules would apply: the plan would be declared unconstitutional unless the state could come forward with the extraordinary justifications called for by strict scrutiny.

129. It unust be admitted that, in distinguishing the cases, the Shaw Court's reading of UJO pressed the limits. 
occurred even im the absence of the racial motivation. ${ }^{130}$ The Court said that the districts in Shaw could not rationally be understood as anything other than an "effort to segregate voters by race."131 UJO, on the other hand, could be explaimed as an attempt to adhere to "traditional districting principles." 132 If this characterization of the New York legislature's purpose was correct, then the plaintiff in UJO, under Mt. Healthy and Arlington Heights, had not established the discrimmatory purpose necessary to state an equal protection claim, because the district could have been explained without reference to a racially discriminatory purpose. Thus, Shaw and UJO are reconcilable in that the plaintiff in UJO failed to meet the Shaw Court's later understanding of discriminatory purpose. ${ }^{133}$

The second distimction is more compelling. The Court distinguished Shaw and UJO on the pleadings. ${ }^{134}$ According to the Shaw Court, the UJO plaintiff claimed that it had been injured because its voting strength had been diluted. ${ }^{135}$ Of the eight Justices who participated in the UJO decision, five resolved UJO in accor-

130. A classic mixed motive case is Mt. Healthy City School District Board of Education v. Doyle, 429 U.S. 274 (1977). The district court found that Doyle had been released from employment because he had engaged in conduct protected by the First Amendment. Id. at 283. The Supreme Court accepted these findings, but the Court nevertheless held that it did not follow that Doyle was entitled to reinstatement. Id. at 284. Justice Rehnquist, writing for a unanimous Court, held that if the school board could show that it would have taken the same action in the absence of the protected conduct, then Doyle could not demonstrate discriminatory purpose. Id. at 287; see also Village of Arlington Heights v. Metropolitan Hous. Dev. Corp., 429 U.S. 252, 270-71 n.21 (1977) (decided the same day as Mt. Healthy) (noting that if the defendant can show that the impermissible decision would have been reached in the absence of the impermissible motive, then discriminatory purpose has not been shown); Hunter v. Underwood, 471 U.S. 222, 228 (1985) (reaffirming Mt. Healthy and Arlington Heights).

131. Shaw v. Reno, 113 S. Ct. 2816, 2829 (1993).

132. Id.

133. The plausibility of this distinction turns on the plausibility of the Court's rejection of the assumption that racially discriminatory purpose can be directly inferred from the express purpose of complying with $\S 5$ of the Voting Rights Act. See supra note 77 and accompanying text.

134. This is an odd distinction given that both cases were decided on motions to dismiss. On a motion to dismiss, the Court is obliged to consider all the possible theories under which the plaintiff might recover and allow the case to go forward if it can find such a theory, even if that theory is not included in the plaintiff's complaint. See Conley v. Gibson, 355 U.S. 41, 45-46 (1957) ("[A] complaint should not be dismissed for failure to state a claim unless it appears beyond doubt that the plaintiff can prove no set of facts in support of his claim which would entitle him to relief.").

135. Shaw, 113 S. Ct. at 2829. 
dance with the Court's previously established framework for vote dilution cases. ${ }^{136}$ Of these five, three Justices held that the UJO plaintiffs had failed to state a claim on the grounds that the New York statute did not constitute a "racial slur or stigma" and left white voters with better than proportional representation. ${ }^{137}$ Two Justices concluded that the statute in UJO did not minimize or cancel out a racial group's voting strength. ${ }^{138}$

The vote dilution framework, the Shaw Court held, simply does not apply to a redistricting plan that "offends principles of racial equality." ${ }^{139}$ Nothing in UJO, according to the Shaw Court, prevented the plaintiffs in Shaw from bringing the analytically distimct claim that a reapportionment plan that "cannot be understood as anything other than an effort to segregate citizens into separate voting districts on the basis of race without sufficient justification" violates the Equal Protection Clause. ${ }^{140}$ The implication is that the plamtiff in UJO simply pleaded the wrong injury. It failed to state a claim because the injury it claimed, vote dilution, was not present in the case. ${ }^{141}$ The Shaw plaintiffs, on the other hand, did not allege vote dilution. Rather, they alleged "that the dehiberate segregation of voters into separate districts on the basis of race violated their constitutional right to participate in a "color-blimd' electoral process." 142 As to this injury, the Shaw plaintiffs stated a viable claim. Thus, the traditiontl rationale interpretation is able to meet the internal objections raised against it.

Like the irregular shape interpretation, however, the traditional rationale is subject to external objections as well as internal objections. First, the Court's recent decision in an Ohio redistricting case, Voinovich $v$. Quilter, ${ }^{143}$ supports the irregular shape

136. Id. This is the Shaw Court's interpretation of UJO.

137. UJO v. Carey, 430 U.S. 144, 165-66 (1977) (White, J., concurring).

138. Id. at $179-80$ (Stewart, J., concurring).

139. Shaw, 113 S. Ct. at 2829.

140. Id. at 2830.

141. It must be emphasized that this is the Shaw Court's reading of UJO. The real explanation might be that the cause of action recognized in Shaw was not recognized at the time UJO was decided, and this fact should not rule out the possibility of a distinct claim being accepted in the future.

142. Shaw, $113 \mathrm{~S}$. Ct. at 2824.

143. 113 S. Ct. 1149 (1993). In Quilter, the Ohio apportionment board had redistricted the Ohio legislature and, in the process, intentionally created several majority-minority districts. Id. at 1153 . The plaintiffs claimed that these districts illegally "packed" minority voters into a small number of districts. The plaintiff's theory was that instead of being insufficiently attentive to race, Ohio had been too attentive. The plaintiffs argued that 
interpretation's claim that Shaw is not the kind of broad attack on race-based classifications implied by the traditional rationale. ${ }^{144}$ In Quilter, the Court held that as long as no illegal vote dilution occurs as a result of reapportionment, states do not violate the Voting Riglits Act, no matter how race-conscious they might have been in drawing the districts. ${ }^{145}$ As commentators have observed,

If this were all there were to Quilter, the meaning of Shaw would be clear: in the absence of vote dilution, race-conscious districting, in and of itself, would pose no legal problems. Only when carried to particular kinds of extremes, as in Shaw, would distinctive constitutional issues arise. But Quilter is not quite this transparent. The Court expressly reserved the question of whether race-conscious redistricting per se might violate the Fourteenth or Fifteenth Amendments. ${ }^{146}$

After Shaw, Ohio's redistricting efforts would be subject to strict scrutiny review: if they did not survive strict scrutiny review, they would violate the Fourteenth Amendment. Thus, the traditional rationale interpretation of Shaw is reconcilable with Quilter; Quilter held only that Olio's redistricting efforts did not violate the Voting Rights Act.

Second, if Shaw recognizes a theory of harm under which any purposeful racial classification is subject to strict scrutiny (as the traditional rationale does), then a substantial number of districts are invalid. ${ }^{147}$ As the Court noted in Shaw, in drawing voting districts, a legislature "always is aware of race."148 If a legislature is aware of race in the same way that it is aware of other demographic factors like economic status, religious persuasion, or political affiliation, strict scrutimy may be triggered. The Court, however, has indicated that as long as district limes are drawn with these other demographic factors in mind and the districts themselves

race-conscious districting over and above that required by the Voting Rights Act violates the Act and the Constitution. Id.

144. See Pildes \& Niemi, supra note 6, at 496-98.

145. Quilter, $113 \mathrm{~S}$. Ct. at 1156 . In Quilter, the district court found that in the districts at issue, there was no racially polarized voting. In the absence of such polarization, black and white voters are essentially fungible. Therefore, race-conscious districting cannot dilute voting strength when voting patterns are not explained by race. Id. at 1158 (citing Quilter v. Voinovich, 794 F. Supp. 695, 700-01 (N.D. Ohio 1992)).

146. Pildes \& Niemi, supra note 6 , at 497.

147. See Aleinikoff \& Issacharoff, supra note 7, at 607-08.

148. Shaw v. Reno, 113 S. Ct. 2816,2826 (1993). 
accord with the traditional principles of compactness, contiguity, and mamtaining the integrity of political subdivisions, such districts do not necessarily involve "impermissible race discrimination." These other factors make the legislature's choice nonarbitrary in the constitutional sense and thus able to withstand strict scrutiny.

In the alternative, the Court's position might be that a "regular" district is subject to a variant of mixed motive analysis in determining discrimmatory purpose. Under this analysis, a plaintiff would not be able to show discriminatory purpose if race were one small factor among many leading to the choice of district boundaries. If a district accords with traditional districting principles, for instance, the Court's point imight have been that since the district would have been drawn that way anyway (for traditional districting reasons), then under the mixed motive analysis, the plaintiff could not show the kind of discriminatory purpose necessary to state an equal protection claim. . $^{50}$

The final objection is that the theory of harm advocated by the traditional rationale is, like the theory of expressive harm advocated by the irregular shape interpretation, unable to meet the jurisdictional standing requirement. ${ }^{151}$ The argument is that since all members of the classified racial group suffer the proposed mjury, the claim runs afoul of the ban on generalized grievances. ${ }^{152}$ It is well settled, however, that "standing may be based on an interest created by the Constitution."153 For example, if the Congress were to adopt a law prohibiting all religious worship this law would deprive all citizens of a constitutional right; nevertheless, any individual citizen would liave standing. ${ }^{154}$ As the Court explained in United States v. Students Challenging Regulatory Agency Procedures (SCRAP),

Nor ... could the fact that many persons shared the same injury be sufficient reason to disqualify from seeking review ... any person who had in fact suffered injury. ... . To deny standing to persons who are in fact injured simply because many others are

149. Id.

150. See supra note $130-31$ and accompanying text.

151. See supra notes $55-56$ and accompanying text.

152. See Warth v. Seldin, 422 U.S. 490,499 (1975) (holding that standing is prevented when the "asserted harm is a 'generalized grievance' shared in substantially equal measure by all or a large class of citizens").

153. Joint Anti-Fascist Refugee Comm. v. McGrath, 341 U.S. 123, 152 (1951).

154. ERWIN CHEMERINSKY, FEDERAL JURISDICTION \& 2.3, at 77 (2d ed. 1989). 
also injured, would mean that the most injurious and widespread Government actions could be questioned by nobody. ${ }^{155}$

Thus, standing is upheld as long as the plaintiff claims to have personally suffered a harm. ${ }^{156}$

The theory of harm advocated by the traditional rationale interpretation thus satisfies the standing requirement because the right to be free from race-conscious classification is a personal, constitutional right. ${ }^{157}$ The expressive theory of harm, on the other hand, does not satisfy the standing requirement because it does not involve a personal right. Instead, it gives rise to nonindividualized harms and thus falls prey to the ban on generalized grievances. ${ }^{158}$

\section{CONCLUSION}

Contrary to the view of several commentators, Shaw v. Re$n o^{159}$ is not enigmatic, applicable only to voting districts of highly irregular shape and having no implications beyond such districts; it is an extremely important decision with profound implications for equal protection jurisprudence generally. Many commentators who have considered this issue consider Shaw is an anomaly. Such consensus notwithstanding, courts should recognize that in cases like $U J O$, when the plaintiff is unable to plead any imjury beyond the racial classification itself, courts should no longer dismiss complaints for failure to state a claim.

This Note has rejected the interpretation of Shaw that claims that the irregular shape of the district constitutes a cognizable mjury. This interpretation is unable to explain critical parts of the Court's reasoning and runs afoul of the jurisdictional standing requirement. A better interpretation of Shaw suggests that implicit in the Court's rationale lies a theory of injury that is the next logical step in the Court's equal protection jurisprudence. Under this theory of injury, racial discrimination itself establishes a consti-

155. 412 U.S. $669,686,688$ (1973).

156. CHEMERINSKY, supra note $154, \S 2.3$, at 54 .

157. E.g., City of Richmond v. J.A. Croson Co., 488 U.S. 469, 493 (plurality opinion) ("To whatever racial group these citizens belong, their 'personal rights' to be treated with equal dignity and respect are implicated by a rigid rule erecting race as the sole criterion in an aspect of public decisionmaking.").

158. See supra notes 55-56 and accompanying text.

159. 113 S. Ct. 2816 (1993). 
tutionally cognizable injury. The corresponding interpretation of Shaw does not suffer the infirmities of the interpretation offered by the commentators. It is able to explain how a plaintiff proceeding under such a theory could invoke the jurisdiction of a federal court, and it is reconcilable with the Court's insistence that Shaw did not overturn UJO. Consequently, courts should recognize that Shaw is not an anoinaly and they should look to its rationale whenever they are confronted with a race-based equal protection claim. 